\title{
Strategy disclosures by listed financial services companies: Signalling theory, legitimacy theory and South African integrated reporting practices
}

\author{
W. van Zij|* C. Wöstmann and W. Maroun \\ University of the Witwatersrand, 1 Jan Smuts Avenue, Braamfontein, 2000, South Africa
}

*To whom all correspondence should be addressed

Wayne.Vanzijl@wits.ac.za

\begin{abstract}
This paper investigates the current extent of social-, environmental- and economic- (SEE) related strategy disclosure of companies listed in the financial services sector of the Johannesburg Stock Exchange. It uses signalling and legitimacy theory to analyse the findings from a developed SEE strategy-related disclosure checklist.

The paper finds social and environmental strategy-related disclosure is still secondary to economic strategy-related disclosures. This may be due to persistent focus on providers of financial capital and the need to perform financially. Further, the subsector's business model and how closely the subsector interacts with their customers is seen as a driver of social and environmental strategy-related disclosure to maintain their legitimacy and to reduce information asymmetry, reduce cost of capital and assure investors that these factors are being appropriately managed by the entity.
\end{abstract}

Following from above, the banking, insurance and real estate subsectors presented the most strategy-related disclosure. This was linked to their high public accountability and daily interaction with customers, necessitating the need to manage their legitimacy and address adverse selection. The paper also proposes some areas for future research to understand the potential obstacles to incorporating social and environmental concerns into strategy and related disclosures.

\section{Introduction}

Integrated reporting is the most recent advance in the sustainable business practice and reporting movement. According to the International Integrated Reporting Committee (IIRC) (2013), an effective integrated report is not just an aggregation of an annual and sustainability report. It should provide users with a detailed explanation of how an organisation manages financial and non-financial risks in order to generate sustainable returns (IIRC, 2013; de Villiers et al., 2014; King, 2016). Consequently, an integrated report shifts the historical focus of financial statements to a forwardlooking account of the value creation process (ibid). The reporting entity should illustrate how management uses financial, manufactured, human, intellectual, natural and social/relationship capitals in the value creation process (IIRC, 2013). This should be linked clearly to the entity's strategy, business model and key risks (Stubbs and Higgins, 2014; Raemaekers et al., 2016).

The extent to which companies have actually embraced an integrated perspective of corporate reporting is, however, unclear. The release of the IIRC's framework on integrated reporting has coincided with an increase in the extent of environment, social and governance (ESG) disclosures (Padia, 2012; Carels et al., 2013; Raemaekers and Maroun, 2014). There is also evidence of risk assessment and management including ESG considerations (PWC, 2013; Loate et al., 2015) and non-financial information being incorporated in multiple sections of the integrated reports
(Solomon and Maroun, 2012; Stent and Dowler, 2015). A number of weaknesses have, however, been identified.

Despite the call for a clear and concise review of the value creation process (IIRC, 2013), users complain that integrated reports are repetitive, contain unnecessary detail and obscure important information (Solomon and Maroun, 2012; Miller and Graham, 2013). The extent to which financial and nonfinancial information is being integrated is also superficial. ESG considerations are not consistently incorporated in risk assessment and management plans (Massa et al., 2015; Raemaekers et al., 2016) and forward-looking analysis dealing with each of the IIRC's capitals is seldom provided (PwC, 2015). Related to this, non-financial disclosures are generic and do not give insight into how ESG factors impact the ability of the organisation to generate returns in the short-, medium- and long-term (PwC, 2014; Atkins and Maroun, 2015).

Critics argue that these flaws are the result of a persistent focus on financial indicators (Brown and Dillard, 2014; Stubbs and Higgins, 2014; Maroun, 2016). The last twenty years have seen an increase in the extent of non-financial disclosures (KPMG, 2010; Adams et al., 2016) but accounting and finance remain the primary discourse for articulating corporate performance (Gray et al., 1995; Atkins et al., 2015a). As a result, ESG issues are interpreted as being of secondary importance as opposed to important strategic issues which can have a material effect on the business model and the generation of future returns (Cho et al., 2012; 
Tregidga et al., 2014). Related closely to this, the drive for corporate sustainability is not always seen as consistent with a key objective of profit maximisation for the benefit of debt and equity providers (ibid). As such, ESG reporting can be used to satisfy the general social expectation for more comprehensive disclosures in an integrated report (see Institute of Directors in Southers Africa (IOD), 2011; de Villiers and Alexander, 2014) but is not regarded as value relevant from a financial perspective (Atkins et al., 2015b; Marcia et al., 2015).

To explore the tension between financial and non-financial reporting in more detail, this paper examines the integrated reports of Johannesburg Stock Exchange- (JSE) listed companies in the financial services sector. It focuses on the extent of social, environmental and economic issues being included in strategy-related disclosures.

This sector was chosen because of the significant role it plays in the local economy and the fact that these institutions provide the financial infrastructure for different social, environmental and economic (SEE) initiatives undertaken by their customers. This sector can also influence the extent to which their investees engage with pressing SEE-related issues (Maroun and Atkins, 2015; King, 2016) and should be setting the tone for responsible investment and corporate reporting (Institute of Directors in Southern Africa (IOD), 2011). As such, investigating if social or environmental issues are being incorporated in the industry's strategyrelated disclosures will shed light on the progress made by a core sector of the South African economy to provide more integrated explanations of the value creation process (see IIRC, 2013). In addition, because this paper concentrates on disclosures at the strategic level (rather than in total), it provides indirect evidence on whether or not integrated reporting is promoting integrated thinking as demonstrated by the inclusion of non-financial metrics in a company's strategic considerations.

\section{Literature review}

\section{Theoretical framework}

Signalling and legitimacy theory are most commonly used to explain the proliferation of non-financial reporting over the last 20 years (Cho et al., 2015). From a signalling perspective, ESG reporting is not just a social or political imperative. Environmental and social issues can affect an organisation's operations and impact its ability to generate financial returns (Integrated Reporting Committee of South Africa (IRCSA), 2011). As a result, high quality ESG disclosures signal that potentially significant business risks are being effectively managed, reducing information asymmetry and lowering the cost of equity (de Villiers and van Staden, 2011; De Klerk et al., 2015). This view is supported by a growing body of research which finds a positive correlation between nonfinancial reporting and return on equity (de Klerk and de Villiers, 2012), the quality of an organisation's management (Churet and Eccles, 2014) and a firm's perceived sustainability (Eccles and Saltzman, 2011).
Legitimacy theory does not focus on the direct financial value of ESG reporting. Instead, firms disclose non-financial information in order to manage stakeholder expectations and demonstrate allegiance to prevailing social norms (O'Donovan, 2002; Higgins and Walker, 2012; Loate et al., 2015). Patten (1992; 2002; 2005), for example, finds that a firm faced with a specific environmental crisis increases the extent of non-financial reporting to reassure stakeholders that the organisation is managing the negative event. The same applies when a company is subject to critical publicity in the popular press (Brennan and Merkl-Davies, 2014) or seeks to win an influential stakeholder's approval (de Villiers and van Staden, 2006). Similarly, larger organisations are more likely to complement financial information with separate sustainability or corporate social responsibility reports than smaller firms due to additional political pressure and public interest (Thorne et al., 2014). In each instance non-financial reporting is used to demonstrate that the firm is aware of important ESG issues, is responding to weaknesses and remains deserving of stakeholders' continued support (Brennan and Merkl-Davies, 2014; Tregidga et al., 2014).

Short-term financial performance and corporate sustainability are not, however, always consistent (Tregidga et al., 2014). As a result, demands for financial returns by some stakeholders may conflict with the ESG imperatives stressed by others (Cho et al., 2015). Where this is the case, the entity needs to manage carefully how it includes non-financial indicators in its integrated report.

\section{Using non-financial reporting to manage stakeholder expectations}

Where information is relevant for the most influential stakeholders, this needs to be emphasised in corporate communications (Botten, 2009). In a capital market system, the result is that financial information - which addresses the primary information needs of debt and equity providers - is disclosed predominately in the annual or integrated report as opposed to the sustainability report or corporate webpage (de Villiers and van Staden, 2011). In terms of signalling theory, prominent reporting on key financial information is essential for reducing the risk of adverse selection and lowering the cost of capital. The need to maintain legitimacy by managing social expectations cannot, however, be overlooked.

The codification and institutionalisation of best corporate governance and reporting practice necessitates an acceptable level of non-financial reporting (de Villiers and Alexander, 2014; Tregidga et al., 2014). Consequently, an organisation must include at least some ESG information in its communication with stakeholders. If ESG considerations are seen as an essential part of the business model, signalling theory predicts that reporting is driven by the need to demonstrate how the non-financial factors are being managed to preserve or increase firm value and limit the risk of adverse selection. This is amplified by the requirement to report on non-financial issues in order to maintain legitimacy. As a result, ESG disclosures would be included in the primary 
corporate report to stakeholders or in the most prominent sections of that report.

In contrast, if ESG issues are not seen as an integral part of the business model or as a significant business risk, the value relevance of the ESG information is reduced (Marcia et al., 2015). Disclosures are provided primarily to satisfy the expectations of a broad group of stakeholders (in terms of legitimacy theory) who do not have a direct interest in the firm or have only limited influence to demand change. As a result, while legitimacy theory predicts that some ESG reporting is required, the extent of disclosure can be reduced or the information can be included in less prominent sections of the corporate reports (Patten, 2002; de Villiers and van Staden, 2011).

To explore how companies are reporting on non-financial metrics in more detail, the research examines the extent to which social and environmental issues are addressed at a strategic level in integrated reports of South African financial services firms. The researchers posit that a company which provides consumer-focused services, or has a business models with direct links to environmental or social factors, is more likely to identify social and environmental indicators as strategically relevant. This is because of the pressures of a larger group of stakeholders with an immediate interest in the respective firm, as predicted by legitimacy theory (Thorne et al., 2014). At the same time, the easier-to-understand impact of non-financial issues on the scope of the organisation to generate value means that, as per signalling theory, social and environmental disclosures are value-relevant and will be included prominently as strategic issues in the integrated report (de Villiers and van Staden, 2011).

\section{Strategy disclosures}

'Strategy' can be defined as the management of a group of long-term unique activities and resources in order to enhance a firm's value and maintain its position (Porter, 1996). A similar conclusion can be reached based on the IIRC's integrated reporting framework which, as discussed in Section 1, argues that firm value is a function of the management of multiple types of capital transformations in order to generate sustainable returns into the long-run (IIRC, 2013). This implies that the management of the different types of capital under an organisation's direction is not only important for corporate reporting but is also a relevant strategic requirement. To explore this in more detail, the guidance provided by King-III (IOD, 2009) and the IIRC (2013) is used to develop a strategy disclosure matrix. The disclosure items included in this matrix are derived below.

\section{Constructing the data collection instrument}

According to the IIRC (2013), a company's integrated report should have a strategic focus and future orientation. This requires a company to identify and discuss significant risks, opportunities and dependencies resulting from the specific market position and business model. Those charged with governance should incorporate these factors in specific strategies for ensuring the company's short-, medium- and long-term sustainability (IIRC, 2013). The strategy should be updated as new facts or circumstances emerge (Collier and Agyei-Ampomah, 2008). As a result, the following were included in the data collection instrument to determine whether the company's disclosure:

1. Identifies significant risks, opportunities and dependencies resulting from market position and business model.

2. Highlights the relationship between past and future performance.

3. Describes how the organisation is balancing short-, medium- and long-term interests.

4. Describes how past experiences have affect expected future developments.

5. Articulates the availability, quality and affordability of significant capitals used to generate value.

In addition, an integrated report should 'answer the question: Where does the organization want to go and how does it intend to get there' (IIRC, 2013, p. 27).

6. Identifies the organisation's short-, medium- and longterm objectives and determines how it plans to meet these objectives.

7. Identifies the resource allocation plans to implement strategy.

8. Describes the link between strategies and the business model and required changes to the business model.

9. Considers the external environment to identify strategic impacts.

10. Assesses the effect of capitals available on the identified strategy.

The organisation also needs to consider how it plans to maintain its competitive advantage. This can include: stressing the importance of innovation in operating activities (Porter, 1998), development of intellectual capital to drive new approaches to doing business (IRCSA, 2011), efficient utilisation of scarce resources (Collier and Agyei-Ampomah, 2008) and embedding social or environmental issues in the business model as a differentiation tool (Atkins et al., 2016).

11. Differentiates what gives the organisation a sustainable competitive advantage.

A company's strategy needs to be planned and communicated carefully. It cannot contradict the entity's core values, its primary purpose or stakeholders' expectations (IOD, 2009). As a result, the strategy should consider all material risks and opportunities according to a formal risk management and analysis system (Collier and Agyei-Ampomah, 2008). Both the organisation's strategy and related business plans should be reviewed by senior management and, where applicable, internal audit in order to ensure that important issues specific to each of the relevant capitals are addressed (IIRC, 2013) and understood by the organisation and its key stakeholders (IOD, 2009). 
12. Demonstrates how strategy aligns with the purpose of the company and stakeholders' expectations.

13. Demonstrates that the risks relating to strategy and business plans have been thoroughly examined.

14. Identifies risk management processes and systems (including the role played by management).

15. Identifies the role of internal audit in risk management processes.

An appropriate Information Technology (IT) system is required to support the process of identifying risks, assessing their impact and incorporating these in business plans and an organisation's strategy (IOD, 2009). A Chief Risk Officer, with sufficient expertise and authority, should be appointed to ensure effective implementation and monitoring of action plans linked to the entity's strategic goals. This includes a review of the design and implementation of controls to ensure risks and opportunities are continuously identified and responded to by the appropriate members of management. Effective management of stakeholder relations should form an integral part of the business and control environment (IOD, 2009).

16. Identifies a Chief Risk Officer who has sufficient experience and authority to act on strategically important issues.

17. Describes how the IT strategy has been integrated within the company's strategic and business processes.

18. Describes controls to mitigate risks and identify opportunities to promote the realization of the company's strategic goals.

19. Explains how the organisation manages stakeholder relations in order to achieve its strategic goals.

South Africa has one of the highest incidences of HIV/AIDS globally (AIDS Foundation SA, 2015). HIV/AIDS poses significant business risks such as employee absenteeism, decreased productivity, costs associated with counselling and educating the workforce and loss of skills (EE Publishers, 2015). It is, therefore, important for companies to have an informed and effective HIV/AIDS strategy.

\section{Describes the HIV/AIDS strategy [Social strategy disclosure only].}

Finally, Apartheid has had a significant effect on South Africa's socio-economic condition. Numerous measures have been introduced to address the effects of legalised racism, the most notable being the introduction of Black Economic Empowerment (BEE) (de Villiers and van Staden, 2006; Hill and Maroun, 2015). This legislature aims to transform the South African economy by encouraging:

'...meaningful participation of the majority of its citizens and to further create capacity within the broader economic landscape at all levels through skills development, employment

\footnotetext{
${ }^{1}$ The JSE requires those companies whose primary listing is in South Africa to comply with the King-III code or explain why they have not. A company can, therefore, comply with the listing requirements even if it has
}

equity, socio economic development, preferential procurement, enterprise development, ..., promoting the entry of black entrepreneurs into the mainstream of economic activity' (South African Government, 2015).

BEE policies are a material factor affecting an organisation's human and social/relationship capital. At the same time, BBE initiatives can lead to significant changes to procurement policies, labour costs and levels of equity ownership (see, for example, Department of Mineral Resources, 2010) with the result that a socially-focused state initiative is a relevant strategic consideration for South African organisations.

\section{Describes the company's BEE strategy [Social strategy disclosure only].}

The disclosures identified above are aggregated and form the basis of a strategy disclosure matrix. This is explained in more detail in the method section.

\section{Method}

The research is conducted in an interpretive style. Although data is collected and analysed using a quantitative technique, the aim is not to test for causal relationships, develop generalizable results or conduct an econometric analysis of reporting trends (Coetsee and Stegmann, 2012; Maroun and Jonker, 2014). The study is an exploratory one. It considers the extent to which companies are dealing with SEE issues in their strategy-related disclosures and how this reflects the operationalisation of signalling or legitimacy considerations, as discussed in the literature review.

\section{Population and sample}

The population is all JSE-listed companies in the financial services sector as at 31 December 2013. Companies with no integrated reports available were excluded. These included companies whose primary listing is in another country and are, therefore, exempt from complying with the JSE's requirement ${ }^{1}$ to produce an integrated report. A final sample of 55 companies was analysed (see Appendix B). These companies are listed in Appendix C.

\section{Data collection and analysis}

As explained in the literature review, a data collection instrument was developed interpretively by the researchers, based on the guidance provided in King-III, the IIRC and some of the prior research on ESG reporting by South African companies. The instrument is an easy-to-understand matrix which lists the different strategy-related considerations which should be included in an integrated report and is used to record whether or not these disclosure items are discussed in the context of financial (economic), social/transformational (social) or natural (environmental) capital.

not complied with a specific aspect of the King-III code by explaining why it has not done so. 
Using the same approach as Padia (2012) and Makiwane and Padia (2013), the support researcher read each integrated report to gain a sense of its content and structure. The reports were then analysed by subsection or heading to identify strategy-related disclosures using the data collection instrument. Once the disclosures were located, the support researcher examined each disclosure to determine if the relevant strategic issue related to a financial (economic) or non-financial (social or environmental) consideration. The disclosure has been coded accordingly. This resulted in each integrated report being read several times until all of the sections in the reports had been processed and the identified strategy disclosures had been coded as either financial, social or environmental in nature.

Where a disclosure was identified, a score was assigned as follows:

0 No disclosure;

1 Limited disclosure around strategy given in this area (well below average)

2 Partial disclosure around strategy given in this area (below average)

3 Adequate disclosure around strategy given in this area (average)

4 Well defined disclosure around strategy given in this area (above average) or

5 Extensive disclosure around strategy given in this area (excellent).

(Adapted from Padia (2012))

The same scoring system was applied to all SEE disclosures. To ensure the reliability of the scoring process, the disclosure matrix was piloted using two companies' integrated reports. The same two companies' reports were then analysed and scored again after a few days to assess consistency and accuracy of the scoring. The initial and subsequent scorecards were compared to ensure consistency. Once the researchers were satisfied that the disclosure checklist was complete and could be applied consistently, the remaining integrated reports were scored.

The scoring system is subjective but the aim is not to 'measure' the disclosures in a positivist sense. The data were aggregated and analysed in a way which allowed for the interpretation of the findings according to the defined theoretical frameworks. Further, no attempt was made to judge the perceived usefulness of the disclosures. This is an inherent limitation of the research but it avoids incorporating excessive subjectivity and ensures that company scores are comparable. The final data collection instrument is included in Appendix A.
After all of the integrated reports were scored, descriptive statistics were generated for each subsector in the financial services sector (according to the JSE) and by type of disclosure. A relatively small data set (and the interpretive style of the paper) precluded the use of detailed econometric analysis. As the data were not normally distributed, a nonparametric Friedman Test was used to test if, in total, there were statistically significant differences between SEE disclosures provided by the companies under review. In addition, SEE disclosures were considered separately to determine if there were statistically significant variations in the level of SEE disclosures by subsector. Based on these results, the researchers ranked the subsectors according to the extent of SEE disclosures at the strategic level. An easy-tointerpret matrix was prepared to contrasts the extent of strategy disclosures focused on financial (economic) and nonfinancial issues (social and environmental) based on the ranking of the average disclosure scores. The results and analysis are presented in the following sections.

\section{Results}

Figure 1 shows the composition of companies analysed by subsector of the financial services according to the JSE. The majority of companies are in financial services $(32.7 \%)$, followed by real estate firms $(25.5 \%)$. Banks comprise the smallest subsector (12.7\%).

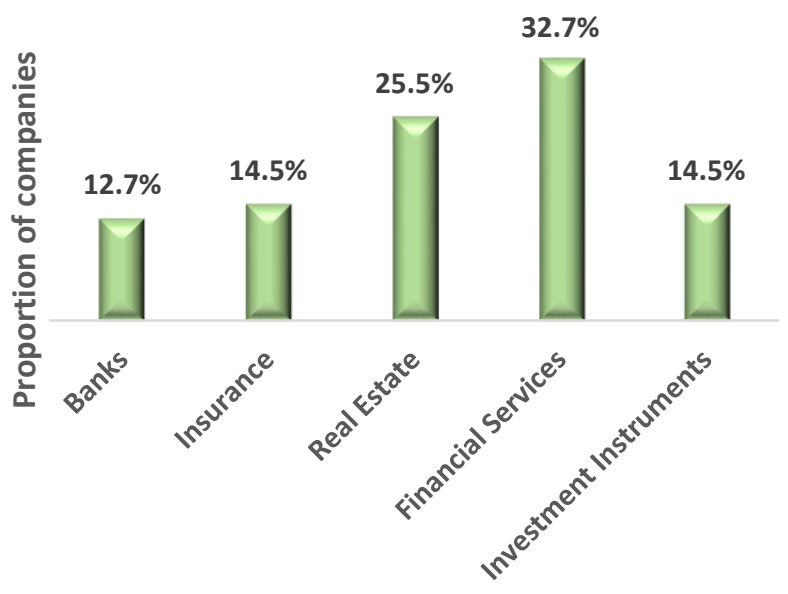

Figure 1: Sample by subsector

Table 1 summarises the mean disclosure scores by subsector and according to type of strategy-related disclosure (social, environmental and economic). 
Table 1: Mean disclosure scores

\begin{tabular}{|c|c|c|c|c|c|}
\hline & \multirow[b]{2}{*}{$\begin{array}{l}\text { Number of } \\
\text { companies }\end{array}$} & \multicolumn{3}{|c|}{ Disclosure frequency mean } & \multirow[b]{2}{*}{$\begin{array}{l}\text { Subsector } \\
\text { average }\end{array}$} \\
\hline & & $\begin{array}{l}\text { Environmental } \\
\text { strategy }\end{array}$ & $\begin{array}{l}\text { Social } \\
\text { strategy }\end{array}$ & $\begin{array}{l}\text { Economic } \\
\text { strategy }\end{array}$ & \\
\hline Banks & 7 & 1.8286 & 2.2143 & 3.3857 & 2.4762 \\
\hline Insurance & 8 & 0.8125 & 1.6875 & 3.0000 & 1.8333 \\
\hline Real Estate & 14 & 2.0464 & 1.5065 & 2.8321 & 2.1284 \\
\hline Financial Services & 18 & 0.4528 & 0.8283 & 2.1722 & 1.1511 \\
\hline $\begin{array}{l}\text { Investment } \\
\text { instrument }\end{array}$ & 8 & 1.0813 & 1.0114 & 1.4625 & 1.1850 \\
\hline Total/average & 55 & 1.2443 & 1.4496 & 2.5705 & 1.7548 \\
\hline
\end{tabular}

The subsector average (Table 1) shows that, overall, banking firms provided the most information on their strategy followed by companies in the real estate subsector. Financial services and investment instrument firms provide the least disclosure. The rankings are summarised in Table 2.

Table 2: Rankings

\begin{tabular}{l|l|l|l|l}
\hline & \multicolumn{3}{l|}{ Rankings } & 年 \\
\cline { 2 - 5 } & $\begin{array}{l}\text { Environ- } \\
\text { mental } \\
\text { strategy }\end{array}$ & $\begin{array}{l}\text { Social } \\
\text { strategy }\end{array}$ & $\begin{array}{l}\text { Economic } \\
\text { strategy }\end{array}$ & Overall \\
\hline Banks & $2^{\text {nd }}$ & $1^{\text {st }}$ & $1^{\text {st }}$ & $1^{\text {st }}$ \\
\hline Insurance & $4^{\text {th }}$ & $2^{\text {nd }}$ & $2^{\text {nd }}$ & $3^{\text {rd }}$ \\
\hline Real Estate & $1^{\text {st }}$ & $3^{\text {rd }}$ & $3^{\text {rd }}$ & $2^{\text {nd }}$ \\
\hline $\begin{array}{l}\text { Financial } \\
\text { Services }\end{array}$ & $5^{\text {th }}$ & $5^{\text {th }}$ & $4^{\text {th }}$ & $5^{\text {th }}$ \\
\hline $\begin{array}{l}\text { Investment } \\
\text { Instrument }\end{array}$ & $3^{\text {rd }}$ & $4^{\text {th }}$ & $5^{\text {th }}$ & $4^{\text {th }}$ \\
\hline
\end{tabular}

Table 1 and 2 show that the banking industry has the highest mean social disclosure score (2.21), followed by the insurance (1.69) and real estate (1.51) firms. The financial (0.83) and investment instrument (1.01) firms provided the least strategic social-related disclosures which were also below the average score for all of the subsectors (1.45). The rankings were very similar for economic disclosures. Banks provided the most detail (3.39) while financial services (2.17) and investment instrument firms (1.46) included the least amount of detail. In contrast, real estate companies provided the most environmental-related strategic disclosures (2.05). Banks (1.83) and investment instrument firms (1.08) ranked second and third respectively. Companies in the insurance (0.81) and financial services (0.45) subsectors include the least amount of social issues in their strategic disclosures.

Most strategic disclosures were focused on economic issues (average total score of 2.57). This was followed by social (average total score of 1.45) and environmental disclosures (average total score of 1.24). Using the overall disclosure score determined by calculating the mean score for each SEE indicators, the following results were generated by a Friedman test.
Table 3A: Ranks

\begin{tabular}{l|l|l|l}
\hline & $\begin{array}{l}\text { Environmental } \\
\text { disclosure }\end{array}$ & $\begin{array}{l}\text { Social } \\
\text { disclosure }\end{array}$ & $\begin{array}{l}\text { Economic } \\
\text { disclosure }\end{array}$ \\
\hline Mean Rank & 1.53 & 1.65 & 2.82 \\
\hline
\end{tabular}

Table 3B: Test statistics (Friedman Test)

\begin{tabular}{l|l|l|l}
\hline $\mathbf{N}$ & Chi-Square & Df & Asymp. Sig. \\
\hline 55 & 57.774 & 2 & .000 \\
\hline
\end{tabular}

Table 3A and 3B show that there is at least one pair of scores with statistically significantly differences at the $1 \%$ level of significance $\left(\chi^{2}(2)=57.774, \mathrm{p}<.001\right.$. $)$. More specifically, the mean economic disclosure score $(M R=2.85, n=55)$ is significantly higher than the mean environmental $(\mathrm{MR}=1.53$, $\mathrm{n}=55)$ and social $(\mathrm{MR}=1.65, \mathrm{n}=55)$ disclosure scores. The scores on the non-financial disclosures (with $95 \%$ confidence intervals overlapping) are not statistically different.

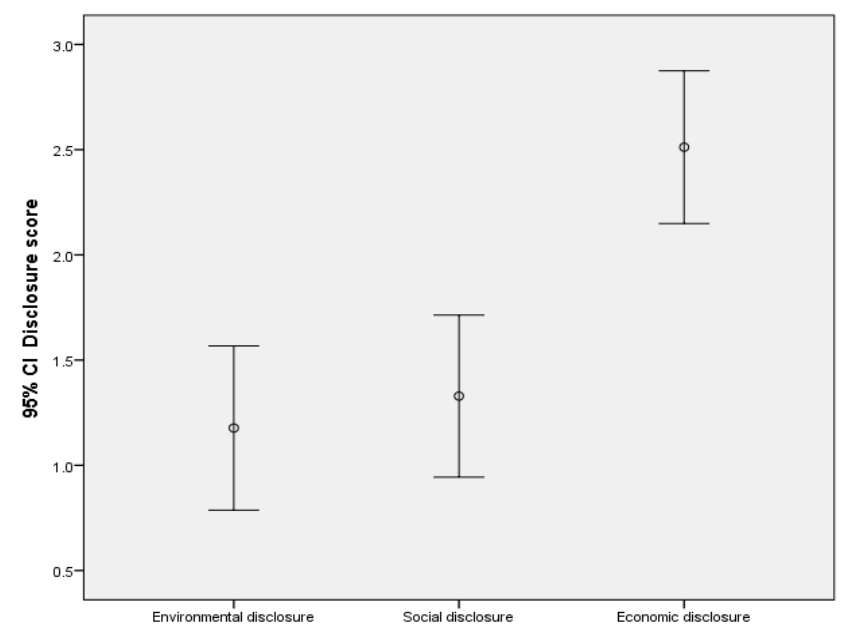

Figure 2: Confidence intervals

Finally, the researchers considered if there were statistically significant differences in SEE disclosures (each considered separately) according to subsector. Results are summarized in Table 4A and Table 4B. 
Table 4A: Mean ranking

\begin{tabular}{l|l|l|l}
\hline Subsector & $\begin{array}{l}\text { Environmenta } \\
\text { l strategy }\end{array}$ & $\begin{array}{l}\text { Social } \\
\text { strategy }\end{array}$ & $\begin{array}{l}\text { Economic } \\
\text { strategy }\end{array}$ \\
\hline Banks & 34.93 & 37.07 & 37.29 \\
\hline Insurance & 25.44 & 34.00 & 34.50 \\
\hline Real Estate & 38.71 & 29.50 & 31.96 \\
\hline $\begin{array}{l}\text { Financial } \\
\text { Services }\end{array}$ & 19.22 & 23.14 & 24.06 \\
\hline $\begin{array}{l}\text { Investment } \\
\text { Services }\end{array}$ & 25.50 & 22.38 & 15.31 \\
\hline
\end{tabular}

Table 4B: Test statistics ${ }^{\text {a,b }}$

\begin{tabular}{|c|c|c|c|}
\hline & \begin{tabular}{|l|}
$\begin{array}{l}\text { Chi- } \\
\text { Square }\end{array}$ \\
\end{tabular} & df & \begin{tabular}{|l|} 
Asymp. \\
Sig. \\
\end{tabular} \\
\hline $\begin{array}{l}\text { Environmental } \\
\text { disclosure }\end{array}$ & 13.968 & 4 & .007 \\
\hline Social disclosure & 6.161 & 4 & .187 \\
\hline Economic disclosure & 10.638 & 4 & .031 \\
\hline \multicolumn{4}{|l|}{ a. Kruskal Wallis Test } \\
\hline \multicolumn{4}{|c|}{ b. Grouping Variable: Sector listed under } \\
\hline
\end{tabular}

The Kruskal-Wallis test revealed no significant social disclosure score differences among the subsectors $\left(\chi^{2}(4)\right.$ $=6.161, \mathrm{p}>.05)$. In contrast, there is at least one pair of subsectors with statistically significate differences in environmental disclosures $\left(\chi^{2}(4)=13.968, \mathrm{p}<.01\right)$. The untabulated custom tables with Bonferroni correction show that real estate firms $(\mathrm{MR}=38.71, \mathrm{n}=14)$ provide more environmental disclosures than financial services companies $(\mathrm{MR}=19.22, \mathrm{n}=18)$ and that these differences are statistically significant. The Kruskal-Wallis test also showed that there is at least one pair of subsectors with economic disclosure scores which differ significantly $(\chi 2(4)=10.638, \mathrm{p}<.05)$. The un-tabulated custom tables with Bonferroni correction reveal that banks $(\mathrm{MR}=37.29, \mathrm{n}=7)$ provide more details on economic issues in their strategy-related disclosures than investment instrument companies $(M R=15.31, n=8)$. These differences are statistically significant.

\section{Discussion and analysis}

There is a growing awareness of the importance of environmental issues such as climate change, habitat loss, income inequality and employee health and safety (de Villiers and van Staden, 2006; Jones and Solomon, 2013; Raemaekers et al., 2016). The result is that organisations are under pressure to demonstrate how social and environmental concerns are being taken into account in their business models and day-to-day operations in order to maintain legitimacy (O'Donovan, 2002; Patten, 2002; Adams et al., 2016). Stakeholders' expectations for high quality nonfinancial reporting have been reinforced by: (1) the limitations of historical financial statements for providing insight into long-term value creation (IRCSA, 2011) ; (2) the emphasis on social and environmental metrics in codes of corporate governance (IOD, 2009) and (3) demands for corporate reports which explain the interconnections between different types of capital (IIRC, 2013). As a result, and as predicted by legitimacy theory, all of the companies in the financial services industry include social and environmental strategy-related disclosures in their integrated reports.

At the same time, the fundamentals of the capital market system remain relevant. In particular, the need to generate financial returns for debt and equity providers has not been diminished by sustainability and integrated reporting (Dillard and Reynolds, 2008; Atkins et al., 2015a). As a result, Table 1 and Table 2 show that economic issues are discussed by all companies under review in their strategy disclosures and that less detail is provided on social and environmental issues at the strategic level (Table 3A; Table 3B).

This is consistent with the findings of the prior research which finds that legitimacy considerations necessitate some prominent disclosure of social and environmental issues but, because of the relevance of financial imperatives, companies must emphasise economic factors at the strategic level (see de Villiers and van Staden, 2011; Tregidga et al., 2014). On closer inspection, however, differences in the approach to incorporating SEE issues in strategic disclosures included in the integrated report emerge.

The Kruskal-Wallis Test does not reveal statistically significant variation in social disclosures by subsector but this is not the case with environmental and economic disclosures. There is at least one pair of scores showing statistically significant differences (Table 3A and Table 3B) implying that, despite the overall emphasis on economic-related strategic disclosures at the industry level, reporting strategies vary by subsector. To examine the interconnection between reporting on SEE strategic indicators in more detail, Table 5 shows the relative emphasis on the different disclosures.

For this purpose, as the Friedman Test (Table 3A and 3B) revealed no statistically significant differences between social and environmental disclosures, these are grouped as 'Social and environmental reporting (non-financial disclosures) in Table 5. The frequency of these disclosures is contrasted with the frequency of economic disclosures. The mean rankings for SEE disclosures are used to position the subsectors of firms to show the relative emphasis on SEE issues in their strategy reporting.

\section{Table 5: Financial v non-financial reporting matrix}

\begin{tabular}{l|l|l|l|l}
\hline \multirow{2}{*}{} & \multirow{2}{*}{} & \multicolumn{3}{|l}{ Social and environmental reporting } \\
\cline { 3 - 5 } & & Low & Moderate & High \\
\hline \multirow{2}{*}{} & Low & & $\begin{array}{l}\text { Investment } \\
\text { instruments }\end{array}$ & \\
\cline { 3 - 5 } & Moderate & $\begin{array}{l}\text { Financial } \\
\text { services }\end{array}$ & & Insurance \\
\cline { 3 - 5 } & High & & Real estate & Banks \\
\hline
\end{tabular}

Companies ranked first or second per disclosure type (Table 2) are interpreted as placing a high emphasis on the respective disclosures. Those ranked last reveal that they are placing a 
low emphasis on the relevant disclosures. All other subsectors are reported as placing moderate emphasis on either financial or non-financial disclosures. Using this schematic, two broad approaches to corporate reporting are identified.

\section{Low volume reporting}

Financial services and investment instrument firms provide the least strategy-related disclosures (Table 2). As shown in Table 1, their mean SEE scores are below the industry average.

Form a signalling theory perspective, the results imply that information asymmetry is low because stakeholders have a detailed understanding of the relevant strategic considerations. As a result, the marginal benefit of additional disclosure does not justify the added cost of reporting (de Villiers and van Staden, 2011). This applies to both financial and non-financial disclosures. Similarly, legitimacy theory predicts that firms respond to societal expectations for transparent reporting on important social and environmental issues by increasing the quantum of non-financial disclosures (Patten, 2002). As a result, the low mean disclosure scores (Table 1) suggest that pressures from different stakeholder groups for dealing with environmental and social issues at the strategic level are low. Alternately, with stakeholders not demanding an account of how corporate strategy is incorporating non-financial considerations, the organisations maintain a relatively low level of disclosure in order to avoid additional scrutiny (de Villiers and van Staden, 2006) or the risk of extensive disclosure inviting calls for further changes to the business model (Cho et al., 2015).

Nevertheless, the purpose of integrated reporting is to demonstrate how each of the capitals under a company's control is managed in order to create long-term value (IIRC, 2013; PWC, 2013). The low mean environmental and social disclosure scores of the financial services and investment instrument subsectors (Table 1), coupled with the fact that the subsectors provide limited SEE disclosures in total (Table 2; Figure 2), can be interpreted as an indication that these firms do not regard non-financial metrics as strategically relevant. This finding is surprising given the recent release of the Code for Responsible Investment in South Africa (CRISA) which is designed to encourage the investment community to take cognizance of social and environmental issues when making investment decisions (IOD, 2011; Atkins and Maroun, 2015). Similarly, the Equator Principles should form a significant component of a financial services company's environmental strategy and should be disclosed (Amalric, 2005). It is, therefore, possible that the subsectors have not internalized the principles of responsible investment and integrated reporting, with the result that environmental and social issues do not feature in the development of their strategic framework.

Concurrently, despite King-III, the Global Reporting Initiative, the IIRC's framework, CRISA and the Equator
Principles, companies in the financial services sector either cannot identify their environmental and social impact or feel that this is negligible. On the one hand, their business model is such that any environmental or social footprint is indirect. For example, unlike a manufacturing concern, they are unlikely to have significant $\mathrm{CO}_{2}$ emissions, water consumption or biodiversity impacts. Similarly, unlike the mining sector, the financial services and investment instrument firms do not rely significantly on unskilled labour. Nevertheless, it would be reasonable to expect these firms to provide stakeholders with an understanding of how their investment philosophy is evolving to take environmental and social issues into consideration (cf Amalric, 2005). For example - and in line with CRISA (Maroun and Atkins, 2015) and the Equator Principles (Amalric, 2005) - these companies could explain how they are funding clean energy projects or how their risk assessments and discount rates are being adjusted to accommodate key environmental or social indicators.

\section{High volume reporting}

Like companies providing low levels of strategy disclosures, the insurance, bank and real estate subsectors emphasised economic considerations at the strategic level (Table 3A; Table 3B). Social and environmental issues are discussed in more detail (Table 5). The greater emphasis placed on nonfinancial issues may be attributable to the business model. This is most clearly evident when comparing real estate to financial services firms where the Kruskal-Wallis test reported the most statistically significant differences in disclosure scores (Table 4A; Table 4B).

Real estate companies have significant physical assets (as opposed to financial instruments) on their balance sheets which increase direct exposure to, for example, environmental-related risks. For instance, rising sea levels has an immediate impact on a real estate company with material sea-side properties. A financial services institution interprets the same risk only as a possible decline in the fair value of its equity investments, which is likely to be hedged due to diversified investments in different portfolios of assets and investments in off-setting financial instruments. As a result, signalling theory predicts that more environmental disclosures are required to reassure investors that risks are being managed, reduce information asymmetry and manage the effects of environmental issues on the cost of capital.

The real estate subsector is also more subject to pressures from environmentally conscious consumers with the result that prominent non-financial reporting is essential for managing legitimacy. For example, there is growing demand for energy-efficient buildings and low emission construction techniques which could explain why these companies are more likely to identify environmental issues as strategically relevant. This is in contrast to financial services firms which are not directly responsible for the environmental management practices of their investees ${ }^{2}$. It may also be the

\footnotetext{
${ }^{2}$ An examination of shareholder activism in South Africa is beyond the score of this paper.
} 
case that the real estate companies are able to use environmental responsibility as a way of differentiating themselves from competitors to secure their strategic position. Because of the nature of the industry, a comparable approach of investing in environmentally responsible companies may be replicated easily and is, therefore, not a maintainable strategic competitive advantage (see Porter, 1996).

Banks had the second highest environmental disclosures and ranked first for social disclosures (Table 2; Figure 2). While many of the arguments explaining a low disclosure score in the financial services subsector (Section 5.1) may be applicable to the banking, there is an important difference. Companies in the banking subsector include the major commercial banks which engage on a day-to-day basis with general consumers (consider Elsbach and Sutton, 1992; Suchman, 1995; Hooghiemstra, 2000; Bansal and Clelland, 2004). As a result, they are more likely to be subject to consumer pressure and criticism in the popular press than are investment instrument firms which are more focused on niche markets. The same may apply to the insurance subsector which, as shown by Table 2, follows a similar approach to incorporating SEE issues in strategic-related disclosures.

The precise reasons for these disclosure trends cannot be defined but it is possible that banking, insurance and real estate subsectors have a more evolved reporting system and a better understanding of the interconnections between the different types of capital than the other subsectors under review. The results in Table 4A, Table 4B and Table 2 also imply (but do not prove) that there is a relationship between the extent of SEE disclosures in the strategy sections of integrated reports and the type of business model. Those subsectors which offer direct services to their customers or are subject to more public scrutiny are more inclined to provide additional information on their risk exposures and management practices (focused on social or environmental challenges) in order to manage legitimacy considerations. Where the business model is such that the link between social and environmental issues and financial performance is clearer, the need to use non-financial reporting to address legitimacy concerns is amplified by signalling requirements. Prominent social and environmental disclosures signal that the relevant risks are under control and have been incorporated into the firm's strategic plans in order to maintain the confidence of financial capital providers. In contrast, investment and financial instrument firms are, arguably, providing niche services to specific segments of the market. They have a more abstract business model and are less likely to engage directly with the general public. In this complex strategic environment, organisations provide less risk-related information and are also less likely to include environmental and social issues in their strategy-related disclosures.

\section{Conclusion}

This paper examined the extent of SEE disclosures dealing with the strategy of companies listed on the JSE's financial services sector. As predicted by signalling theory, in a capital market context, economic disclosures are important for reducing information asymmetry, lowering the cost of capital and limiting the risk of adverse selection (de Villiers and van Staden, 2011). As a result, companies must report prominently on key economic indicators, something which the financial services industry does by emphasising these factors in its strategy-related disclosures. Non-financial information cannot, however, be overlooked.

There is a growing awareness of the importance of dealing with social and environmental issues to ensure corporate sustainability (IIRC, 2013). As a result, companies are under mounting pressure to disclose non-financial information in their integrated reports and explain how social and environmental challenges are being managed as part of the process of generating financial returns (de Villiers et al., 2014; Atkins and Maroun, 2015). For the South African Financial Services Industry, this means that social and environmental metrics cannot be entirely marginalised. To meet social expectations and secure legitimacy, at least some social and environmental issues must be dealt with prominently in their strategy disclosures. The primary emphasis on financial capital, however, means that nonfinancial reporting at the strategic level is limited.

For financial services and investment instrument firms, in particular, the business model is complex and focused on generating returns for a niche group of stakeholders. In addition, these companies have relatively few daily dealings with the general consumer. Consequently, the societal pressure to manage environmental and social issues (as predicted by legitimacy theory) actively is low. This is especially true given that the link between social and environmental issues and the organisations' business model is only indirect. From a signalling theory perspective, the added cost of additional non-financial reporting is not justified by the financial benefits of the marginal information given to the providers of financial capital. As a result, these two subsectors reported few social and environmental issues at the strategic level and provided the lowest level of disclosure on their corporate strategy in total.

The banking, insurance and real estate subsectors adopt a slightly different reporting strategy. Financial capital remains a primary focus and, accordingly, these companies still emphasise economic issues at the strategic level. Unlike financial services and investment instrument firms, however, social and environmental issues are included to a greater extent in strategy-related disclosures. Banks, insurance companies and real estate managers interact regularly with a relatively broad group of stakeholders. They provide consumer-focused services and/or have business models with direct links to environmental or social factors. Consequently, the relevance of non-financial reporting as a signalling mechanism and managing legitimacy is increased with the result that these non-financial indicators are more likely to be seen as strategically relevant. These results have a number of important implications. 
Firstly, codes of corporate governance (IOD, 2009) and responsible investment practices (IOD, 2011) do not necessarily result in companies in the financial services sector adopting a more integrated approach to corporate strategy. CRISA and the Equator Principles call for environmental and social factors to be taken in the investment analysis and appraisal process (IOD, 2011) and there is mounting scientific evidence on the risks posed to the industry by social and environmental issues (Hill and Maroun, 2015; Atkins et al., 2016). Nevertheless, not all firms in the financial services sector identify these issues as strategically relevant. Consequently, pressures from stakeholders - especially when the link between the business model and social or environmental considerations is easy to determine - may be better drivers of integrated reporting and thinking than codified best practice. Additional research will, therefore, be needed to examine in more detail which stakeholder groups interact with the financial services industry and how these relationships contribute to more detailed analysis of and reporting on the relevance of social and environmental issues, something which this paper has not been able to do.

Secondly, this study stops short of engaging preparers of integrated reports to identify their reporting challenges. Low levels of strategic and environmental reporting may be due to the difficulty of drawing a connection between the business model and non-financial factors and articulating this clearly in the integrated report. As such, future research should concentrate on examining the obstacles to incorporating social and environmental issues in strategic disclosures and provide practical guidance for identifying and reporting on non-financial factors.

Finally, the research focuses on only a single industry in South Africa. The relationship between business model, level of stakeholder engagement and the extent of social and environmental reporting at the strategic level needs to be examined in more detail. This can include studies to compare reporting trends across industries and from country to country. The results of this study show relatively low levels of non-financial detail at the strategic level suggesting that there is a still a far way to go before South African corporates can claim that they have truly adopted an integrated approach to corporate reporting and management. Future researchers can add significant value by identifying those factors which promote integrated thinking and reporting and developing a framework for application by South African companies.

\section{References}

Adams, C.A., Potter, B., Singh, P.J. \& York, J. 2016. 'Exploring the implications of integrated reporting for social investment (disclosures)', The British Accounting Review, 48, 283-296.

Amalric, F. 2005. The Equator Principles: a step towards sustainability. Center for Corporate Responsibility and Sustainability.

Atkins, J., Atkins, B., Thomson, I. \& Maroun, W. 2015a. “Good' news from nowhere: Imagining utopian sustainable accounting', Accounting, Auditing \& Accountability Journal, 28, 651-670.
Atkins, J., Barone, E., Maroun, W. \& Atkins, B. 2016. Bee accounting and accountability in the UK. In: Atkins, K. \& Atkins, B. (eds.) The Business of Bees: An Integrated Approach to Bee Decline and Corporate Responsibility. Sheffield, UK: Greenleaf Publishers.

Atkins, J. \& Maroun, W. 2015. 'Integrated reporting in South Africa in 2012: Perspectives from South African institutional investors', Meditari Accountancy Research, 23, 197-221.

Atkins, J.F., Solomon, A., Norton, S. \& Joseph, N.L. 2015b. 'The emergence of integrated private reporting', Meditari Accountancy Research, 23, 28-61.

Bansal, P. \& Clelland, I. 2004. "Talking trash: Legitimacy, impression management, and unsystematic risk in the context of the natural environment', Academy of Management Journal, 47, 93-103.

Botten, N. 2009. Management accounting business strategy, 2009 Edition, Oxford, United Kingdom, CIMA Publishing.

Brennan, N. \& Merkl-Davies, D. 2014. 'Rhetoric and argument in social and environmental reporting: The dirty laundry case', Accounting, Auditing \& Accountability Journal, 27, 602-633.

Brown, J. \& Dillard, J. 2014. 'Integrated reporting: On the need for broadening out and opening up', Accounting, Auditing \& Accountability Journal, 27, 1120-1156.

Carels, C., Maroun, W. \& Padia, N. 2013. 'Integrated reporting in the South African mining sector', Corporate Ownership and Control, 11, 991-1005.

Cho, C.H., Guidry, R.P., Hageman, A.M. \& Patten, D.M. 2012. 'Do actions speak louder than words? An empirical investigation of corporate environmental reputation', Accounting, Organizations and Society, 37, 14-25.

Cho, C.H., Laine, M., Roberts, R.W. \& Rodrigue, M. 2015. Organized hypocrisy, organizational façades, and sustainability reporting. Accounting, Organizations and Society, 40, 78-94.

Churet, C. \& Eccles, R.G. 2014. 'Integrated reporting, quality of management, and financial rerformance', Journal of Applied Corporate Finance, 26, 56-64.

Coetsee, D. \& Stegmann, N. 2012. 'A profile of accounting research in South African accounting journals', Meditari Accountancy Research, 20, 92-112.

Collier, P. \& Agyei-Ampomah, S. 2008. Management accounting: risk and control strategy, CIMA Publishing, Oxford, 2008, 1st Edition.

De Klerk, M. \& De Villiers, C. 2012. 'The value relevance of corporate responsibility reporting: South African evidence', Meditari Accountancy Research, 20, 21-38.

De Klerk, M., De Villiers, C. \& Van Staden, C. 2015. 'The influence of corporate social responsibility disclosure on share prices: Evidence from the United Kingdom', Pacific Accounting Review, 27, 208-228.

De Villiers, C. \& Alexander, D. 2014. 'The institutionalisation of corporate social responsibility reporting', The British Accounting Review, 46, 198-212. 
De Villiers, C., Rinaldi, L. \& Unerman, J. 2014. 'Integrated reporting: Insights, gaps and an agenda for future research', Accounting, Auditing \& Accountability Journal, 27, 1042-1067.

De Villiers, C. \& Van Staden, C.J. 2006. 'Can less environmental disclosure have a legitimising effect? Evidence from Africa', Accounting, Organizations and Society, 31, 763-781.

De Villiers, C. \& Van Staden, C.J. 2011. 'Where firms choose to disclose voluntary environmental information', Journal of Accounting and Public Policy, 30, 504-525.

Department of Mineral Resources. 2010. Amendment of the BroadBased Socio-Economic Empowerment Charter for the South African Mining and Minerals Industry. Available: http://www.sadpmr.co.za/upload/Mining_Charter.pdf [Accessed 2 April 2015].

Dillard, J. \& Reynolds, M. 2008. 'Green owl and the corn maiden', Accounting, Auditing \& Accountability Journal, 21, 556-579.

Eccles, R. \& Saltzman, D. 2011. Achieving Sustainability Through Integrated Reporting. Stanford Social Innovation Review [Online], Summer. http://202.154.59.182/mfile/files/Jurnal/MIT\%202012$2013 \% 20$ (PDF)/Achieving\%20Sustainability\%20Through\%20Inte grated\%20Reporting.pdf.

EE Publishers. 2015. The effect of HIV/AIDS on your business [Online]. Available: http://www.ee.co.za/article/the-effect-ofhiv.html [Accessed 16 October 2015].

Elsbach, K.D. \& Sutton, R.I. 1992. 'Acquiring organizational legitimacy through illegitimate actions: A marriage of institutional and impression management theories', Academy of Management Journal, 35, 699-738.

Gray, R., Walters, D., Bebbington, J. \& Thompson, I. 1995. 'The greening of enterprise: An exploration of the (NON) role of environmental accounting and environmental accountants in organizational change', Critical Perspectives on Accounting, 6, 211239.

Higgins, C. \& Walker, R. 2012. 'Ethos, logos, pathos: Strategies of persuasion in social/environmental reports', Accounting Forum, 36, 194-208.

Hill, N. \& Maroun, W. 2015. 'Assessing the potential impact of the Marikana incident on South African mining companies: An event method study', South African Journal of Economic and Management Sciences, 18, 586-607.

Hooghiemstra, R. 2000. 'Corporate communication and impression management -- new perspectives why companies engage in corporate social reporting', Journal of Business Ethics, 27, 55-68.

International Integrated Reporting Council (IIRC). 2013. The International Framework: Integrated Reporting. Available: http://www.theiirc.org/wp-content/uploads/2013/12/13-12-08-

THE-INTERNATIONAL-IR-FRAMEWORK-2-1.pdf [Accessed 1 October 2013].

Institute of Directors in Southern Africa (IOD) 2009. The King Code of Governance for South Africa (2009) and King Report on Governance for South Africa (2009) (King-III), Lexis Nexus South Africa, Johannesburg, South Africa.
Institute of Directors in Southern Africa (IOD) 2011. Code for responsible investing in South Africa, Lexis Nexus South Africa, Johannesburg, South Africa.

Integrated Reporting Committee South Africa (IRCSA) 2011. Framework for Integrated Reporting and the Integrated Report. Available: www.sustainabilitysa.org [Accessed 5 June 2012].

Jones, M.J. \& Solomon, J.F. 2013. 'Problematising accounting for biodiversity', Accounting, Auditing \& Accountability Journal, 26, 668-687.

King, M. 23 October 2016. RE: Integrated reporting. Type to Public Lecture.

KPMG 2010. 'A transformation in integrated reporting', Integrated Reporting, 2010, 1-16.

Loate, B., Padia, N. \& Maroun, W. 2015. 'Acid mine drainage in South Africa: A test of legitimacy theory', Journal of Governance and Regulation, 4, 26-40.

Makiwane, T.S. \& Padia, N. 2013. 'Evaluation of corporate integrated reporting in South Africa post King III release South Africa-an exploratory enquiry', Journal of Economic and Financial Sciences, 6, 421-438.

Marcia, A., Maroun, W. \& Callaghan, C. 2015. 'Value relevance and corporate responsibility in the South African context: An alternate view post King-III', South African Journal of Economic and Management Sciences, 18, 500-519.

Maroun, W. 2016. No bees in their bonnet: On the Absence of bee reporting by South African listed companies. In: Atkins, K. \& Atkins, B. (eds.) The Business of Bees: An Integrated Approach to Bee Decline and Corporate Responsibility. Sheffield, UK: Greenleaf Publishers.

Maroun, W. \& Atkins, J. 2015. The Challenges of Assuring Integrated Reports: Views from the South African Auditing Community. In Acca (ed.). London: The Association of Chartered Certified Accountants.

Maroun, W. \& Jonker, C. 2014. 'Critical and interpretive accounting, auditing and governance research in South Africa', Southern African Journal of Accountability and Auditing Research, 16, 51-62.

Massa, L., Farneti, F. \& Scappini, B. 2015. 'Developing a sustainability report in a small to medium enterprise: Process and consequences', Meditari Accountancy Research, 23, 62-91.

Miller, T. \& Graham, M. 2013. 'In pursuit of concise integrated reports', Accounting Perspectives in Southern Africa, 1, 2-8.

O'donovan, G. 2002. 'Environmental disclosures in the annual report', Accounting, Auditing \& Accountability Journal, 15, 344371.

Padia, N. 2012. 'Disclosure of non-financial information on strategy in South African annual reports', African Journal of Business Management, 6(46), 11472-11479.

Patten, D.M. 1992. 'Intra-industry environmental disclosures in response to the Alaskan oil spill: A note on legitimacy theory', Accounting, Organizations and Society, 17, 471-475. 
Patten, D.M. 2002. 'The relation between environmental performance and environmental disclosure: A research note', Accounting, Organizations and Society, 27, 763-773.

Patten, D.M. 2005. 'The accuracy of financial report projections of future environmental capital expenditures: A research note', Accounting, Organizations and Society, 30, 457-468.

Porter, M. 1996. 'What is strategy?', Harvard Business Review, November-December 1996, 61-78.

PwC. 2013. The Value Creation Journey: A survey of JSE Top-40 companies' Integrated reports. Available: www.pwc.com/corporatereporting [Accessed 14 May 2014].

PwC. 2014. The Value Creation Journey: A survey of JSE Top-40 companies' Integrated reports. Available: http://www.pwc.co.za/en/assets/pdf/integrated-reporting-survey2014.pdf [Accessed 7 August 2015].

PwC. 2015. Integrated reporting Where to next? Available: http://www.pwc.co.za/en/assets/pdf/integrated-reporting-survey2015.pdf [Accessed 16 February 2016]

Raemaekers, K. \& Maroun, W. 2014. 'Trends in risk disclosure: Practices of South African listed companies', Accounting Perspectives in Southern Africa, 2, 8-15.

Raemaekers, K., Maroun, W. \& Padia, N. 2016. 'Risk disclosures by South African listed companies post-King III', South African Journal of Accounting Research, 30, 41-60.

Solomon, J. \& Maroun, W. 2012. Integrated reporting: the new face of social, ethical and environmental reporting in South Africa? In Acca (ed.) ACCA. London: The Association of Chartered Certified Accountants.

South African Government. 2015. Broad-based Black Economic Empowerment [Online]. Available: http://www.economic.gov.za/about-us/programmes/economicpolicy-development/b-bbee [Accessed 16 October 2015].

Stent, W. \& Dowler, T. 2015. 'Early assessments of the gap between integrated reporting and current corporate reporting', Meditari Accountancy Research, 23, 92-117.

Stubbs, W. \& Higgins, C. 2014. 'Integrated reporting and internal mechanisms of change', Accounting, Auditing \& Accountability Journal, 27, 1068-1089.

Suchman, M.C. 1995. 'Managing legitimacy: Strategic and institutional approaches', Academy of Management Review, 20, 571610.

Thorne, L., Mahoney, L. S. \& Manetti, G. 2014. 'Motivations for issuing standalone CSR reports: A survey of Canadian firms', Accounting, Auditing \& Accountability Journal, 27, 686-714.

Tregidga, H., Milne, M. \& Kearins, K. 2014. '(Re)presenting 'sustainable organizations", Accounting, Organizations and Society, 39, 477-494.

\section{Appendix A: Data collection instrument}

1. Identifies significant risks, opportunities and dependencies resulting from market position and business model.

2. Highlights the relationship between past and future performance.

3. Describes how the organisation is balancing short-, medium- and long-term interests.

4. Describes how past experiences have affect expected future developments.

5. Articulates the availability, quality and affordability of significant capitals used to generate value.

6. Identifies the organisation 's short-, medium- and longterm objectives and determines how it plans to meet these objectives.

7. Identifies the resource allocation plans to implement strategy.

8. Describes the link between strategies and the business model and required changes to the business model.

9. Considers the external environmental to identify strategic impacts.

10. Assesses the effect of capitals available on the identified strategy.

11. Differentiates what gives the organisation a sustainable competitive advantage.

12. Demonstrates how strategy aligns with the purpose of the company and stakeholders' expectations.

13. Demonstrates that the risks relating to strategy and business plans have been thoroughly examined.

14. Identifies risk management processes and systems (including the role played by management).

15. Identifies the role of internal audit in risk management processes.

16. Identifies a Chief Risk Officer who has sufficient experience and authority to act on strategically important issues.

17. Describes how the IT strategy has been integrated within the company's strategic and business processes.

18. Describes controls to mitigate risks and identify opportunities to promote the realization of the company's strategic goals.

19. Explains how the organisation manages stakeholder relations in order to achieve its strategic goals.

20. Describes the HIV/AIDS strategy [Social strategy disclosure only].

21. Describes the company's BEE strategy [Social strategy disclosure only].

\section{Appendix B: Determination of sample size}

\begin{tabular}{l|l}
\hline Details & Total \\
\hline Total companies in financials sector & 86 \\
\hline No integrated report produced & -3 \\
\hline Suspended from JSE & -5 \\
\hline $\begin{array}{l}\text { No financial year-end since listing date, therefore, no } \\
\text { requirement for integrated report yet }\end{array}$ & -8 \\
\hline Dual listed (Secondary listing on JSE) & -15 \\
\hline Sample size & 55 \\
\hline
\end{tabular}


Appendix C: Sample of companies

\begin{tabular}{|c|c|c|}
\hline Long Name & $\begin{array}{l}\text { Listing } \\
\text { Date }\end{array}$ & $\begin{array}{l}\text { ICB Super Sector } \\
\text { Long Name }\end{array}$ \\
\hline Barclays Africa Grp Ltd & $1986 / 12 / 03$ & Banks \\
\hline Capitec Bank Hldgs Ltd & $2002 / 02 / 18$ & Banks \\
\hline Finbond Group Ltd & $2007 / 06 / 15$ & Banks \\
\hline Firstrand Ltd & $1989 / 03 / 13$ & Banks \\
\hline Nedbank Group Ltd & $1969 / 08 / 20$ & Banks \\
\hline RMB Holdings Ltd & $1992 / 11 / 25$ & Banks \\
\hline Standard Bank Group Ltd & $1970 / 02 / 09$ & Banks \\
\hline Conduit Capital Ltd & $1999 / 03 / 03$ & Insurance \\
\hline Santam Limited & $1966 / 12 / 14$ & Insurance \\
\hline Zurich Insurance Co SA & $1968 / 10 / 30$ & Insurance \\
\hline Clientele Ltd & $2008 / 05 / 19$ & Insurance \\
\hline Discovery Ltd & $1999 / 10 / 21$ & Insurance \\
\hline Liberty Holdings Ltd & $1968 / 12 / 11$ & Insurance \\
\hline MMI Holdings Limited & $1986 / 02 / 19$ & Insurance \\
\hline Sanlam Limited & $1998 / 11 / 30$ & Insurance \\
\hline Attacq Limited & $2013 / 10 / 14$ & Real Estate \\
\hline Ingenuity Property Inv & $2001 / 07 / 02$ & Real Estate \\
\hline Putprop Ltd & $1988 / 07 / 04$ & Real Estate \\
\hline Tradehold Ltd & $2000 / 11 / 06$ & Real Estate \\
\hline Acucap Properties Ltd & $2002 / 03 / 27$ & Real Estate \\
\hline Accelerate Prop Fund Ltd & $2013 / 12 / 12$ & Real Estate \\
\hline Hyprop Inv Ltd & $1988 / 02 / 24$ & Real Estate \\
\hline Octodec Invest Ltd & $1990 / 09 / 20$ & Real Estate \\
\hline Resilient Prop Inc Fund & $2002 / 12 / 06$ & Real Estate \\
\hline Growthpoint Prop Ltd & $1987 / 11 / 27$ & Real Estate \\
\hline Investec Property Fund Ltd & $2011 / 04 / 14$ & Real Estate \\
\hline Redefine Properties Ltd & $2000 / 02 / 23$ & Real Estate \\
\hline Texton Property Fund Ltd & $2011 / 08 / 11$ & Real Estate \\
\hline Tower Property Fund Ltd & $2013 / 07 / 19$ & Real Estate \\
\hline Coronation Fund Mngrs Ld & $2003 / 06 / 13$ & Financial Services \\
\hline Efficient Group Ltd & $2009 / 04 / 20$ & Financial Services \\
\hline Prescient Limited & $2012 / 08 / 20$ & Financial Services \\
\hline Peregrine Holdings Limited & $1998 / 06 / 10$ & Financial Services \\
\hline Ecsponent Limited & $2003 / 02 / 03$ & Financial Services \\
\hline Global Asset Mngment Ltd & $2012 / 12 / 14$ & Financial Services \\
\hline Grand Parade Inv Ltd & $2008 / 06 / 06$ & Financial Services \\
\hline Transaction Capital Ltd & $2012 / 06 / 07$ & Financial Services \\
\hline Trustco Group Hldgs Ltd & $2009 / 02 / 19$ & Financial Services \\
\hline Zeder Inv Ltd & $2006 / 12 / 01$ & Financial Services \\
\hline Cadiz Hldgs Ltd & $1999 / 04 / 14$ & Financial Services \\
\hline Investec Ltd & $1986 / 10 / 15$ & Financial Services \\
\hline JSE Ltd & $2006 / 06 / 05$ & Financial Services \\
\hline Purple Group Ltd & $1998 / 11 / 18$ & Financial Services \\
\hline PSG Group Ltd & $1987 / 11 / 03$ & Financial Services \\
\hline Sasfin Holdings Ltd & $1987 / 11 / 11$ & Financial Services \\
\hline Stratcorp Ltd & $2001 / 12 / 06$ & Financial Services \\
\hline Vunani Ltd & $2007 / 11 / 28$ & Financial Services \\
\hline Andulela Inv Hldgs Ltd & $2008 / 10 / 13$ & Investment Instruments \\
\hline Brimstone Inv Corp Ltd & $1998 / 07 / 08$ & Investment Instruments \\
\hline Hosken Cons Inv Ltd & 1973/11/02 & Investment Instruments \\
\hline Niveus Investments Ltd & $2012 / 09 / 10$ & Investment Instruments \\
\hline Pallinghurst Res Ltd & $2008 / 08 / 20$ & Investment Instruments \\
\hline Rand Merchant Ins Hldgs Ltd & $2011 / 03 / 07$ & Investment Instruments \\
\hline Sabvest Ltd & $1987 / 07 / 02$ & Investment Instruments \\
\hline Trematon Capital Inv Ltd & $1997 / 11 / 20$ & Investment Instruments \\
\hline
\end{tabular}

